\title{
Green economy and its future
}

Atta ul Mustafa ${ }^{1}$, Haleema Afzal ${ }^{2}$, Zunaira Zahoor ${ }^{3 *}$

M.Phil Student, Department of Economics, Minhaj University Lahore, Lahore, Pakistan 1,2,3

attaulmustafa47@gmail.com ${ }^{1}$, halimaafzal96@yahoo.com ${ }^{2}$, zunairazahoor19@gmail.com ${ }^{3 *}$

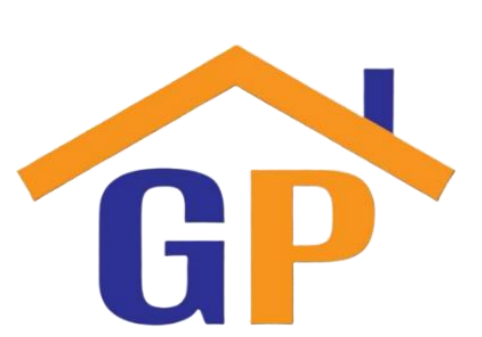

\section{Abstract}

Purpose: This paper tries to find out the current progress of subjective developed and developing countries regarding green economy development.

Research Methodology: This paper uses a graphical radar approach to show countries' overall performance toward the green economy.

Results: This paper concluded that developed countries are ahead of developing in terms of current health expenditure, large forest

Article History

Received on 28 May 2021

Revised on 15 June 2021

Accepted on 24 June 2021 area and tons of national parks. However, they are on the same page in terms of pollution, whether it is air or solid.

Limitations: Several elements restrict this study. The study is carried out in chosen underdeveloped countries and developed ones. The position of the countries is therefore restricted. Consequently, the results and outputs may not apply to geographical sites. Because of unavailability, this study sample may not be sufficient.

Contribution: This study will benefit both developed and developing countries by providing a clear understanding and scenario about the green economy, well-being, and green infrastructure. The findings of this study will be beneficial to institutions, researchers, politicians, the government, and others. Governments and government agencies can plan and promote their strategies and policies to understand green infrastructure and its impact on human health clearly. This study further extends the literature on the green economy and provides a new way of measuring it through its different components. Furthermore, this study can help explain where we stand right now and where we should set sail to.

Keywords: Green economy, Infrastructure, Natural capital, Wellbeing, Social welfare, Forest area, Health expenditure, GDP per capita, Developing countries, Developed countries

How to cite: Mustafa, A. u., Afzal, H., \& Zahoor, Z. (2020). Green economy and its future. Journal of Sustainable Tourism and Entrepreneurship, 2(2), 119-131.

\section{Introduction}

Green Infrastructure is designed not only to control the stormwater, but green infrastructure planned economic, social and natural benefits for the developed and developing countries. An important topic within the recent countries' development methodology is Globalization and rapid urbanization (Gong \& Hu, 2016), each contemplated as the finest threats to worldwide biodiversity (Seto et al., 2012). Furthermore, the world population is expected to expand from 3.9 billion in 2014 to 6.3 billion in 2050, representing a nearly two-thirds rise (United Nations, 2014). From the last few decades, the Human Development Index is used to measure the overall human well-being of the emerging and advanced countries globally, despite the widely stated decreasing trend in environmental services (Wu, 2014). Natural changes will have a massive influence on urban atmospheres. However, it also has a more severe effect on anthropoid welfare because of the deprivation and damage of green space.(Haaland \& Bosch, 2015; Lin \& Fuller, 2013; Tzoulas, Korpela, Venn, Yli-Pelkonen, Kazmierczak, Niemela, et al., $\underline{2007)}$. 
Green infrastructure plays an essential role in management. Moreover, there is a mutual relationship between social capital and natural capital on the welfare of humanity (Gómez-Baggethun et al., 2010, 2013). Green space not solely crucial for the people of both developing and developed countries, but it also increases life's quality (Barrera et al., 2016). Moreover, Green infrastructure helps to promote wellbeing and public health. Mechanical infrastructure domains in such ways have profound challenges for good governance and planning. Frequently increase in technology often decreases the recreational space available for its populations. Developed areas are dynamic ecological systems (Cook et al., 2012; Elmqvist et al., 2004; McHale et al., 2015) which elaborate the natural and social dimensions that can be studied simultaneously (McPhearson et al., 2016; Pickett et al., 2016).

The concept of Green Infrastructures means a network of Greenspace refers to a combination of seminatural and natural regions with other features of the atmosphere which brings a wide range of ecology services and benefit of the well-being (Naumann et al., 2011) and at different measures (Tzoulas, Korpela, Venn, Yli-Pelkonen, Kazmierczak, Niemela, et al., 2007), from few of that have not long been analyzed by social researchers. The emerging thrust of current research activities focused on emergent and developed countries' ecosystem services. Recently, most of the studies on human welfare and green galaxies $(\mathrm{Wu}, 2014)$. Green infrastructure as green space play an important role and have a positive correlation between health and well-being highlighted by several researchers in his studies (Bauduceau et al., 2015; Dunn, 2010; Georgi et al., 2016; Hartig \& Kahn, 2016; Mackerron \& Mourato, 2013; Naumann et al., 2011; Shanahan et al., 2015; WHO, 2015b, 2015a, 2016; Young, 2011) and have concluded that urban blue (water)and green spaces provide several ecological, environmental, economic, socio-cultural benefits to the countries. These refers to the benefits human residents come from ecosystems (Barton \& Pretty, 2010; Bolund \& Hunhammar, 1999; Lundy \& Wade, 2011; Mackerron \& Mourato, 2013; Morris, 2003; Pataki et al., 2010; Termorshuizen \& Opdam, 2009; Tzoulas et al., 2007).

The terms natural capital and green infrastructure are interconnected with each other. Natural capital is focused on ecological assets that can provide services, benefits to humans obtained from the natural environment either directly or indirectly (Ives et al., 2016; Pakzad \& Osmond, 2016), And human beings can stay in touch with nature by social capital. There are some adaptable services associated with urban green infrastructure. It is an effective tool to clean the air quality of industrialized and unindustrialized countries (Dobbs et al., 2014; Dunn, 2010; Gallagher et al., 2015), reduce the impact of heat energy on the land (Dunn, 2010; Monteiro et al., 2019) and alleviate the natural disaster (Pearlmutter et al., 2017). However, green infrastructure performance refined role (Dunn, 2010; Young, 2011), managing water resources (Dunn, 2010; Kambites \& Owen, 2007; Naumann et al., 2011; Young, 2011), prevention of ecosystem and countries redevelopment (McDonald et al., 2005; Wright, 2011). Green infrastructure is key to combating climate change (Moore \& Hunt, 2013; Naumann et al., 2011; Young, 2011) and Human welfare (Naumann et al., 2011).

Green infrastructure can also have effects on human health. Some studies point out, much social welfare from the prospect of social capita promotes mental and physical activities, morbidity, and mortality by providing psychological relaxation and stress alleviation, stimulating social cohesion, supporting the physical activity of developed as well as developing countries (Alaimo et al., 2016; Al-Delaimy \& Webb, 2017; Berg et al., 2015; Hartig et al., 2014; Mackerron \& Mourato, 2013; Pretty et al., 2005; Romanelli et al., 2015; Sandifer et al., 2015; White et al., 2013; WHO, 2016).

The World Health Organization (1948) defines human health as "a state of total physical, mental, and social well-being," not just the absence of illness or disease. Green Infrastructure, Ecosystems, and Human Health: A Conceptual Framework establishes a conceptual framework integrating Green Infrastructure, ecosystems, and human health in the Science for Environment Policy In-depth Report on the Multi-functionality of green infrastructure. 
Green infrastructure has not only affected well-being, but it also affects ecosystem services and health. Following is the list of factors on which GI has an impact are

- Air purification

- Climate and radiation regulation,

- Water purification

- Soil and nutrient cycling

- Habitat provision

- Waste decomposition

- Aesthetic and spiritual

- Noise pollution control

- Air quality;

- Soil structure

- Energy and material cycling

- Water quality;

- Habitat and species diversity

- Ecosystem resilience.

They have based factors of socioeconomic health, physical health, cardiovascular and digestive that are

- Income

- Employment

- Education and lifestyle

- Living and working conditions

- Service and housing access

- Community identification

- Empowerment of society

- Social capital

- Culture

- Endocrine functions and immunity

- Nervous system

- Respiratory system

- Relaxation from stress

- Positive emotions

- Attention capacity

- Cognitive capacity

Green Infrastructure helps to manage air quality by filtering, decomposing and assimilating toxins. Enhanced noise reduction, trees, and shelterbelts assist human settlements with soundproofing of highway noise. Urban Green Infrastructure supports the regulation of urban heat by lowering thermal stress. Green infrastructure promotes physical exercise, which is associated with many physical and mental health aspects. Contact with natural opportunities provides stress alleviation, connected to many physical and mental health aspects, and attractive Green Infrastructure, particularly in cities, improves social cohesion and decreases social inequities (such as diet-related health concerns).

Green Infrastructure advantages include physical, psychological, and socioeconomic advantages and are recognizable at the individual and community levels. Green infrastructure enhances outside time, which in turn is of great concern for physical and mental health (old age, sex, marital and socioeconomic position). Walking green roads and places are linked, for example, to increasing lifespan, decreased blood pressure and body mass index, reduced risk of strokes, cardiovascular disease, and obesity.

Active interaction with nature has been shown to lower blood pressure considerably, while participation in green activities enhances the functioning of youngsters with attention deficit disorder. Visible green areas from home lessen mental weariness and sadness in people. In social cohesiveness at the community level, natural characteristics and open spaces also play a significant role. For example, it has been discovered that Green Infrastructure increases the chance of informal contacts and helps foster 
a feeling of community spirit. It can also lower the rate of crime. Finally, nature can have an aesthetic and cultural value, increasing the sense of well-being and health.

Tree planting is a nature-based solution that helps to improve the health and atmosphere as well(Carrus et al., 2015; Chiesura, 2004; Dobbs et al., 2014; Hofmann et al., 2012; Larondelle et al., 2014; Lee \& Maheswaran, 2011; Lindholst, 2009; Marselle et al., 2015).

This research aimed to discover the current progress of developed and developing countries in terms of green infrastructure development from 2008 to 2014.

\section{Literature review}

Hofmann et al. (2012) highlighted the importance of residential satisfaction in urban GS (green spaces). They took human liking as a key citation in their design. The results suggested that inhabitants were attributing more artificial green infrastructure provided with a low level of maintenance and accessibility.

Carrus et al. (2015) worked on a research paper to build a questionnaire filled by 569 residents from Italian medium to big cities. Results suggest that biodiversity has a favorable impact in resuscitating properties perceived and self-reported advantages to urban and urban green environments from the questioned survey.

Buchel \& Frantzeskaki (2015) devised a three-step technique: services that are perceivable directly, fine seed and shape incomprehensible words provided to urban park users with $Q$ approach. They determined that an aesthetic appreciation was the essential sub-service of ecosystems, but others strongly marked were leisure, air quality management and social conditions.

Akpinar et al. (2016) checked whether green spaces' general specification is associated with general and mental health. For this purpose, they took a sample of 5,148 respondents, resulting in those types of green spaces considered individually rather than aggregated. They used the Ordinary least square method to estimate the sample. They concluded that areas with green infrastructure have fewer health problems. In this area, the level of population is low.

Barrera et al. (2016) used a set of indicators of green spaces at the local and city level in order to bring out existing inequalities. It considered the total area, the quality and the special distribution and accessibility of GS. There were considerable disparities in the number of GS per population in the indicators.

Livesley et al. (2016) carried out a study considering the air quality of trees and the impact of trees on human health. The function of trees in removing air pollutants such as ozone and the release of potentially dangerous organic and allergic chemicals. The study found that trees have a positive impact on human health and well-being. It purifies the polluted air and provides oxygen to human beings.

Marando et al. (2018) researched the populated districts of Rome, Italy, characterized by complicated geography and the Mediterranean climate. They investigated the ecosystem climate regulation services offered by GI. The analysis was carried out. The finding show that GI lessens the hot urban climate significantly in the summers, depending on the GI element and the environmental constraint to which it is subjected.

Calcagnini \& Perugini (2019) conducted the research in which they evaluated by utilizing the combined data, which plays a function of social capital for the welfare, to choose the empirical model for the Italian NUT-3 provinces. They come to an end with the activities carried out by Bank Foundations which are not uniformly spread across Italy and have a good influence on well-being.

Valente et al. (2020) researched 116 Italian provincial capitals that were developed to initially integrate the various topologies of green infrastructures with the supply of services to the ecosystem. The investigation in question determined that the northern cities in Italy are well organized green 
infrastructure and woodland regions. However, the city's southern section is historically green and of a good social health level.

The literature of previous studies stated that green infrastructure has a deep effect on human health and the ecosystem. Parks, paths, and other green infrastructure may do more than promoting growth, sustainability of the environment and social fairness. The increasing study analyzes the link between access to nature and mental health - several studies have shown the relationship between increased green space exposure and enhanced mental health. As planners follow the guidelines described in this sheet, it is noteworthy that green infrastructure offers benefits for both physical and mental health.

\section{Research methodology}

\subsection{Area of study}

The study covers the three developing countries: Pakistan, Bangladesh and India, and the developed countries Canada, USA and UK. This study took time from 2008 to 2014. And compare the result of both developing and developed countries.

\subsection{Sources of data}

This study tries to compare the progress in green economy infrastructure in between developed and developing countries. This study was quantitative and used secondary data for multiple indicators taken from the World Bank database. The data for forestry was taken from the PHA website, and the data for health is taken from the world health organization. The data was taken from 2008 to 2014. The study tried to conclude the progress of developed and developing countries in terms of green infrastructure parameters.

\subsection{Variables}

The following variables were used for this study:

1. Forest area (\% of land area)

2. Total number of national parks

3. Current health expenditure in terms of GDP

4. $\mathrm{Co}_{2}$ emissions from liquid fuel consumption (\% of total)

5. $\mathrm{Co}_{2}$ emissions from solid fuel consumption (\% of total)

6. GDP per capita growth rate.

\subsection{Estimation technique}

Because they are transparent to understand, graphical methods are widely used in statistics. For transparent data analysis and understanding the link between different variables, the graphic representation is extremely vital. A radar chart displays multivariate data as a two-dimensional chart with three or more quantitative variables depicted on axes beginning at the same point. In most cases, the relative location and angle of the axes are uninformative (Holota et al., 2015). The study used a graphical radar approach to determine the progress of three developed and three developing countries in terms of green economy infrastructure development from 2008 to 2014.

\section{Results and Discussion}

\subsection{Results}

In order to provide a variety of benefits such as clean air, better stormwater management and public health, green infrastructure is the integration of nature and ecosystems into cities, towns and regions. It is an organized network of natural areas and open spaces at the regional level, including parks and nature conservation areas, flat corridors, greenways, and wetlands. It comprises parks, rainforest, green roads, green walls, toilets, communal gardens and an urban forest on the scale of the neighborhood and site. This sheet discusses how green infrastructure can promote individual and community health and give information beneficial to the city and regional planners, experts in public health, municipal officials and leaders in the community. 


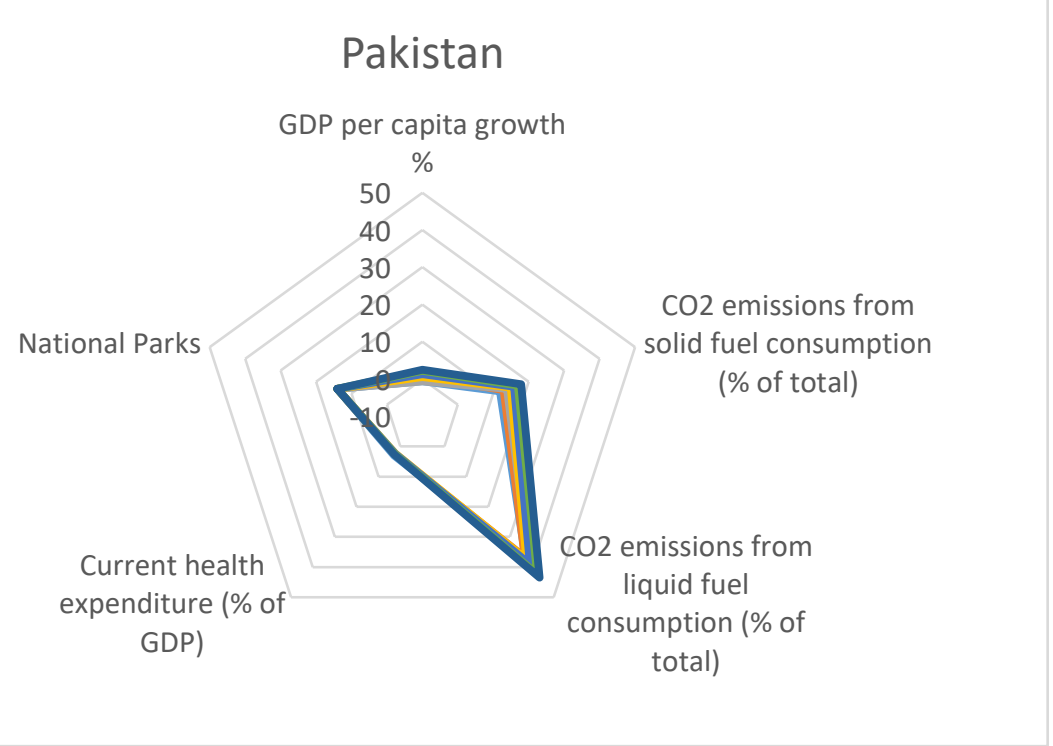

Figure 1. Result of Pakistan

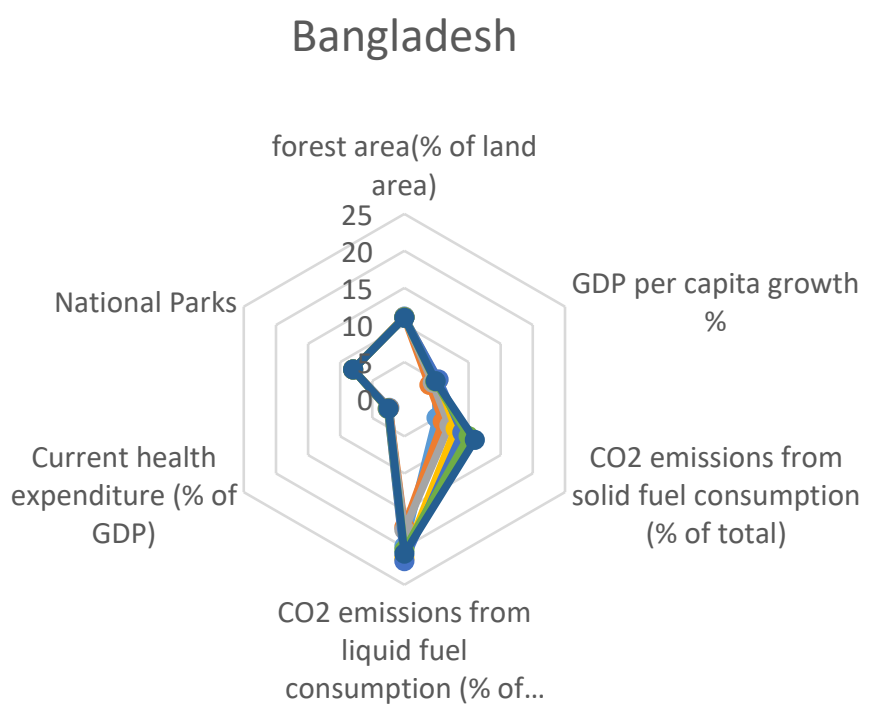

Figure 2. Result of Bangladesh 


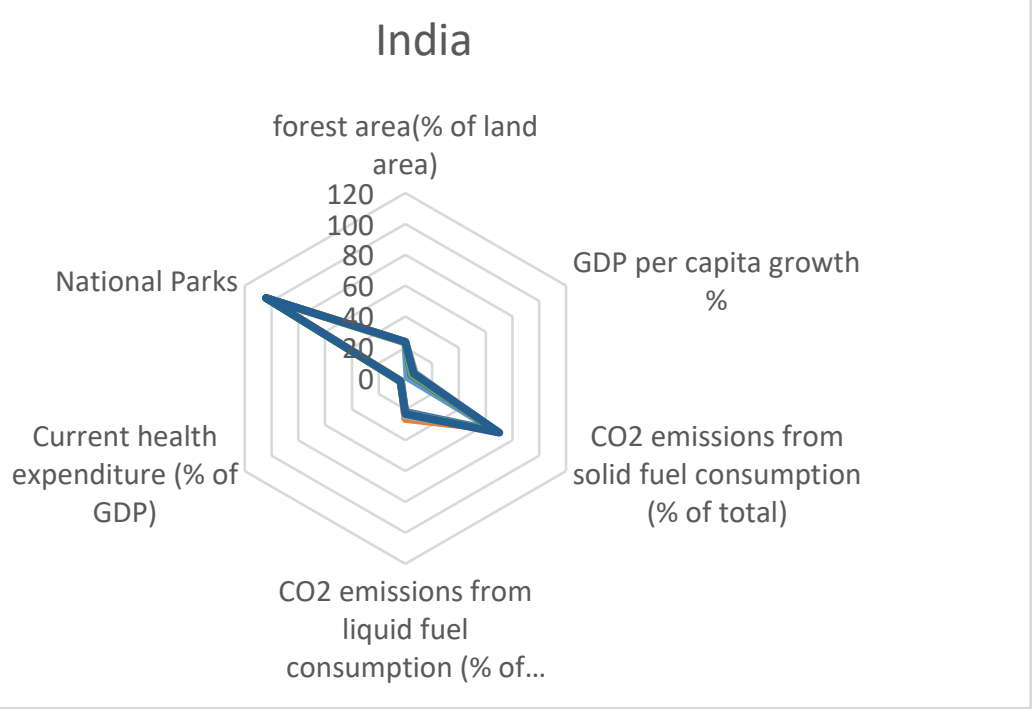

Figure 3. Result of India

The three graphs show the progress and current development of three developing economies, such as Pakistan, India, and Bangladesh, regarding green infrastructure development. As far growth in GDP per capita is concerned, no country is shown tremendous growth, which dictates that people's living standards in these economies are not improving. In addition, on the negative side, the consumption of $\mathrm{Co}_{2}$ in both solid and liquid is growing at a tremendous rate. Moreover, the current health expenditure in all these countries is in extremely low condition as well. And in terms of forest area, Pakistan has only negligible land while others still have something to work. So, we can conclude that the progress in these three countries is not going in the desired direction. And special attention may be needed to put a back economy in the way of the green economy.

\subsubsection{Developed Countries}

\section{Canada}

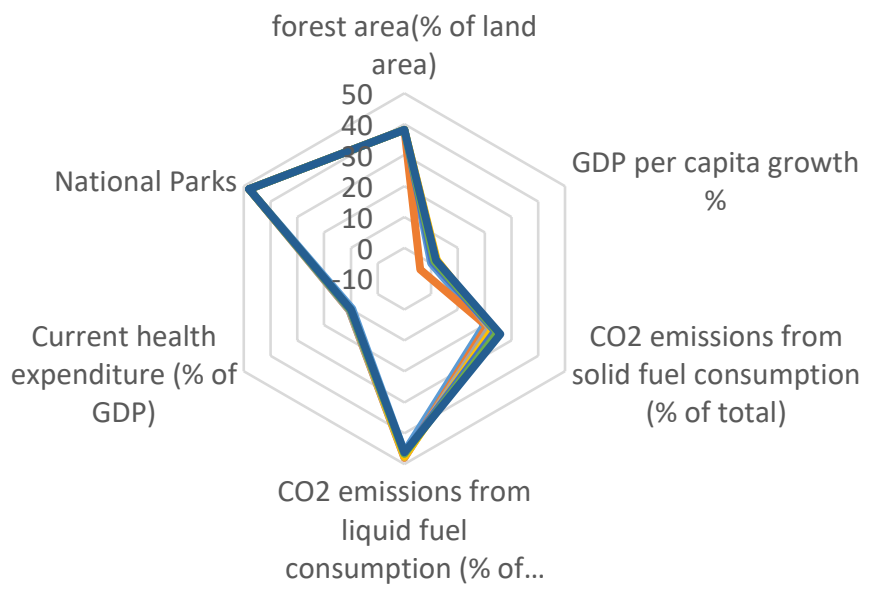

Figure 4. Result of Canada 


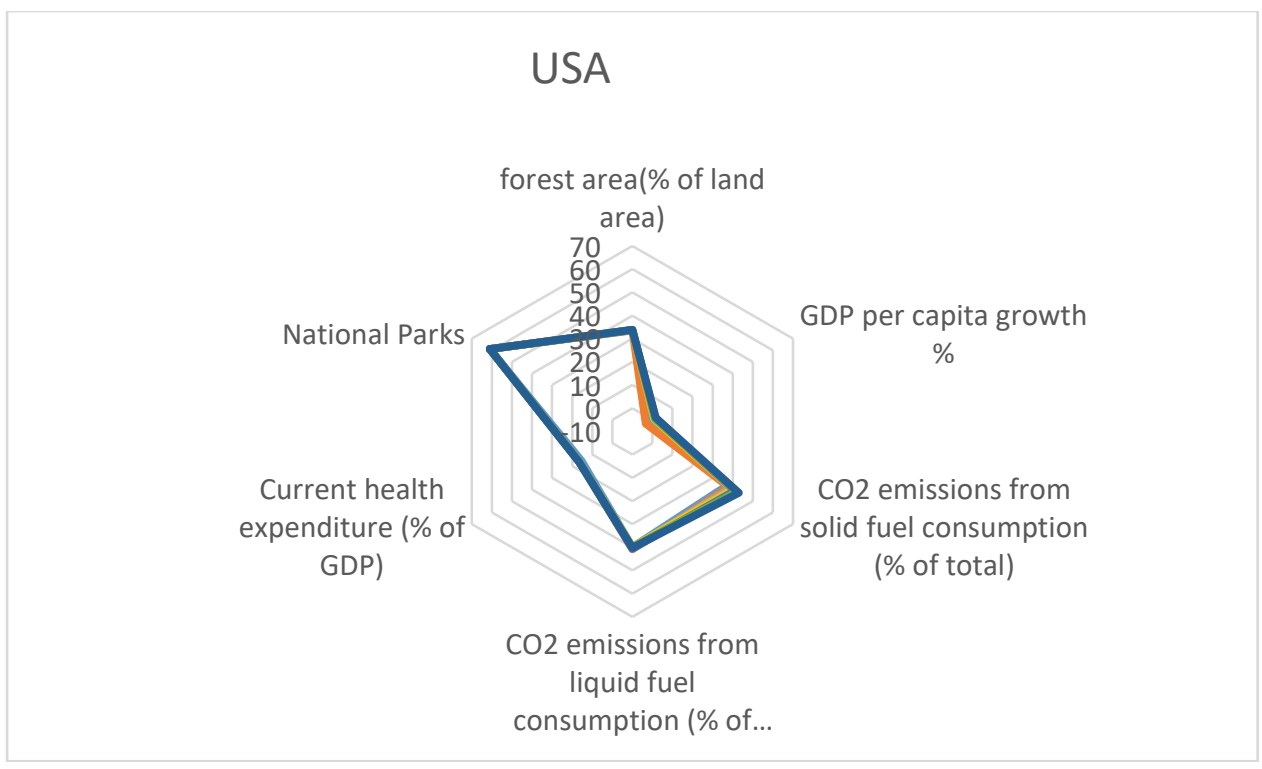

Figure 5. Result of USA

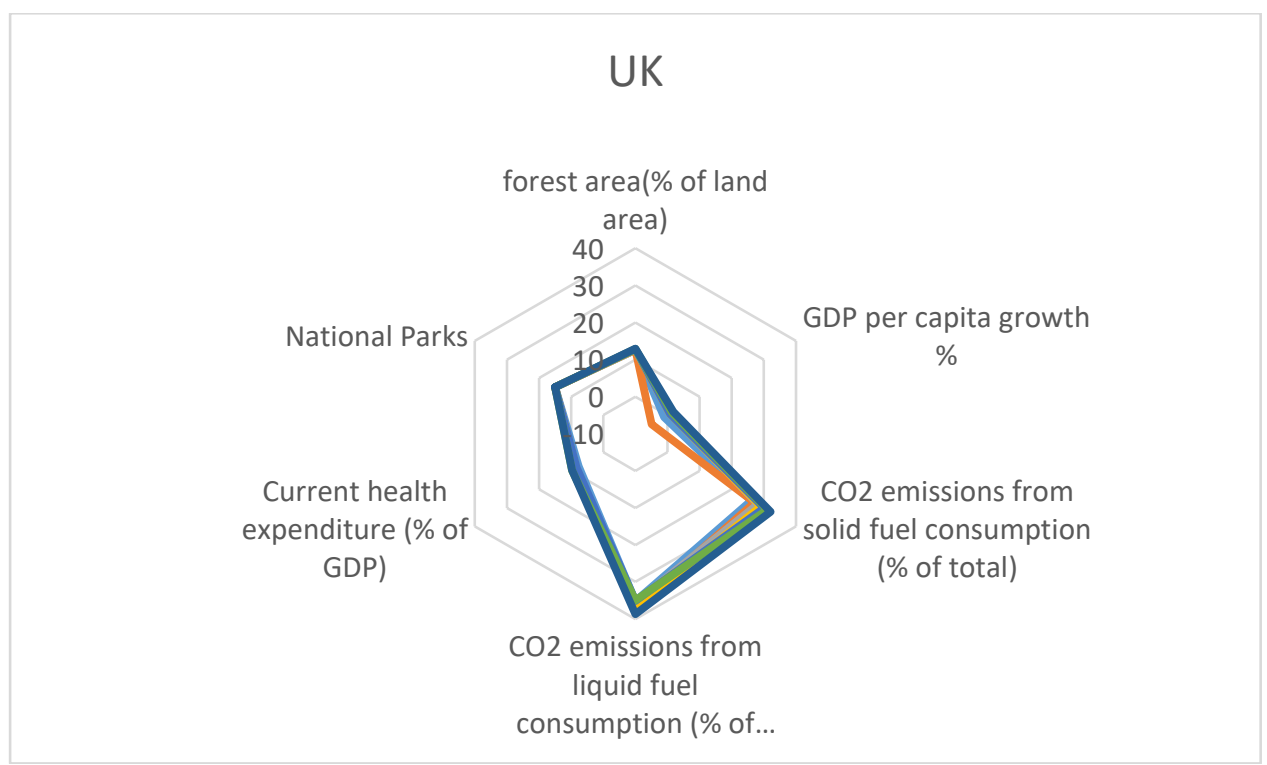

Figure 6. Result of the UK

The first difference we can see is the availability of forest areas in a developed country. They have got quite an area for making air pollution accessible through the trees. Moreover, their health expenditure is also quite showing a high standard of living for people. However, their GDP per capita growth rate is not impressive and almost the same for developing countries. In addition, the consumption of $\mathrm{Co}_{2}$ in both solid and liquid states is relatively high as well. So, in terms of pollution, they are in a bad state as well. The Canada and USA have tons of national parks as compared to the UK. So, overall, to live standard indicators, these developed countries have done well, but more is needed to boost GDP per capita growth rate to boost facilities and standards for people further.

\subsection{Discussion}

From the last few decades Evaluating, the influence of development on environment and biodiversity objectives and functions has been the most important research concentration in most ecological and environmental studies of cities $(\mathrm{Wu}, 2014)$. The purpose of this research is to find out the role of green infrastructure on developed and developing countries that help improve lives and reduce polluting emissions, as we increase the number of parks and forest areas in countries that help purify the air and save from servals diseases. We took the time from 2008 to 2014 to show the effect of green 
infrastructure on both developed and underdeveloped countries. From the radar graph, countries with many parks and forest areas have fewer health diseases by overcoming the emissions.

\section{Conclusion and contribution}

This paper tried to link the progress in terms of infrastructure development in developing and developed countries. For this purpose, we took three developing countries, namely Pakistan, Bangladesh, Indian and three developed countries UK, USA, Canada. The eight years of data were used only because of the limitations and accessibility of data. The multiple aspects of green infrastructure in subjective countries were studied and concluded that developed countries are ahead in current health expenditure and forest areas. The sizeable current health expenditure is evident because of their sizeable federal budget. In terms of pollution, whether air or solid pollution, they are on the same page. So, we conclude that a bit of effort is needed in developed countries to overcome pollution while a ton of effort is needed in developing countries to tackle this progress and put a back economy on track toward a green economy.

This study will benefit both developed and developing countries by providing a clear understanding and scenario about the green economy, well-being, and green infrastructure. The findings of this study will be beneficial to institutions, researchers, politicians, the government, and others. Governments and government agencies can plan and promote their strategies and policies to understand the green infrastructure and its impact on human health clearly. This research further extends the literature on the green economy and provides a new way of measuring it through its different components. Furthermore, this study can help explain where we stand right now and where we should set sail to

\section{Limitations and direction of study}

Several elements restrict this study. The study is carried out in chosen underdeveloped countries and developed ones. The position of the countries is therefore restricted. Consequently, the results and outputs may not apply to geographical sites. Because of unavailability, this study sample may not be sufficient. This study can be expanded by taking more countries, by taking city-level data from different countries.

\section{Recommendations}

Governments should encourage promoting a greener economy to build green jobs, foster sustainable growth, and promote the MDGs. In all relevant policy sectors and policies at the local, national, regional and global level, suitable instruments are employed to integrate the green economy. It includes strategic environmental and climatic assessments, social impacts assessments, environmental and social standards and green procurement.

Green growth and a green economy are both an opportunity and a challenge "In the eradication of poverty and sustainable development." In politics, business and civil society, effective institutions and competent decision makers are necessary to provide fresh momentum to choices to achieve sustainable development and assure ecologically sound pathways for development.

\section{Acknowledgment}

The authors appreciate the anonymous reviewers' comments for increasing the quality of this work.

\section{References}

Akpinar, A., Barbosa-Leiker, C., \& Brooks, K. R. (2016). Does green space matter? Exploring relationships between green space type and health indicators. Urban Forestry \& Urban Greening, 20, 407-418. https://doi.org/10.1016/j.ufug.2016.10.013

Alaimo, K., Beavers, A. W., Crawford, C., Snyder, E. H., \& Litt, J. S. (2016). Amplifying health through community gardens: A framework for advancing multicomponent, behaviorally based neighborhood interventions. Current Environmental Health Reports, 3(3), 302-312. https://doi.org/10.1007/s40572-016-0105-0 
Al-Delaimy, W. K., \& Webb, M. (2017). Community gardens as environmental health interventions: Benefits versus potential risks. Current Environmental Health Reports, 4(2), 252-265. https://doi.org/10.1007/s40572-017-0133-4

Barrera, F. D. L., Reyes-Paecke, S., \& Banzhaf, E. (2016). Indicators for green spaces in contrasting $\begin{array}{lllll}\text { urban } & \text { settings. } & \text { Ecological } & \text { Indicators, } & 62,\end{array}$ https://doi.org/10.1016/j.ecolind.2015.10.027

Barton, J., \& Pretty, J. (2010). Urban ecology and human health and well-being. Urban Ecology, 202229. https://doi.org/10.1017/CBO9780511778483.010

Bauduceau, N., Berry, P., Cecchi, C., Elmqvist, T., Fernandez, M., Hartig, T., Krull, W., Mayerhofer, E., N, S., Noring, L., Raskin-Delisle, K., Roozen, E., Sutherland, W., \& Tack, J. (2015). Towards an EU research and innovation policy agenda for nature-based solutions \& re-naturing cities: Final Report of the Horizon 2020 Expert Group on "Nature-based Solutions and Re-naturing Cities." Publications Office of the European Union. https://doi.org/10.2777/765301

Berg, M., Wendel-Vos, W., van Poppel, M., \& Maas, J. (2015). Health benefits of green spaces in the living environment: A systematic review of epidemiological studies. Urban Forestry \& Urban Greening, 14. https://doi.org/10.1016/j.ufug.2015.07.008

Bolund, P., \& Hunhammar, S. (1999). Ecosystem services in urban areas. Ecological Economics, 29(2), 293-301. https://doi.org/10.1016/S0921-8009(99)00013-0

Buchel, S., \& Frantzeskaki, N. (2015). Citizens' voice: A case study about perceived ecosystem services by urban park users in Rotterdam, the Netherlands. Ecosystem Services, 12, 169-177. https://doi.org/10.1016/j.ecoser.2014.11.014

Calcagnini, G., \& Perugini, F. (2019). Social capital and well-being in the Italian provinces. SocioEconomic Planning Sciences, 68, 100668. https://doi.org/10.1016/j.seps.2018.11.005

Carrus, G., Scopelliti, M., Lafortezza, R., Colangelo, G., Ferrini, F., Salbitano, F., Agrimi, M., Portoghesi, L., Semenzato, P., \& Sanesi, G. (2015). Go greener, feel better? The positive effects of biodiversity on the well-being of individuals visiting urban and peri-urban green areas. Landscape and Urban Planning, 134, 221-228. https://doi.org/10.1016/j.landurbplan.2014.10.022

Chiesura, A. (2004). The role of urban parks for the sustainable city. Landscape and Urban Planning, 68(1), 129-138. https://doi.org/10.1016/j.landurbplan.2003.08.003

Cook, E., Hall, S., \& Larson, K. (2012). Residential landscapes as social-ecological systems: A Synthesis of multi-scalar interactions between people and their home environment. Urban Ecosystems, 15, 19-52. https://doi.org/10.1007/s11252-011-0197-0

Dobbs, C., Kendal, D., \& Nitschke, C. R. (2014). Multiple ecosystem services and disservices of the urban forest establishing their connections with landscape structure and sociodemographics. Ecological Indicators, 43, 44-55. https://www.cabdirect.org/cabdirect/abstract/20143180295

Dunn, A. (2010). Siting green infrastructure: Legal and policy solutions to Alleviate Urban Poverty and Promote healthy communities. Boston College Environmental Affairs Law Review, 37(1), 41. https://lawdigitalcommons.bc.edu/ealr/vol37/iss1/3/

Elmqvist, T., Colding, J., Barthel, S., Borgström, S., Duit, A., Lundberg, J., Andersson, E., Ahrné, K., Ernstson, H., Folke, C., \& Bengtsson, J. (2004). The dynamics of social-ecological systems in urban landscapes: Stockholm and the National Urban Park, Sweden. Annals of the New York Academy of Sciences, 1023, 308-322. https://doi.org/10.1196/annals.1319.017

Gallagher, J., Baldauf, R., Fuller, C. H., Kumar, P., Gill, L. W., \& McNabola, A. (2015). Passive methods for improving air quality in the built environment: A review of porous and solid barriers. Atmospheric Environment, 120, 61-70. https://doi.org/10.1016/j.atmosenv.2015.08.075

Georgi, B., Isoard, S., Asquith, M., Garzillo, C., Swart, R., Timmerman, J. G., \& Romanovska, L. (2016). Urban adaptation to climate change in Europe 2016-Transforming cities in a changing climate. https://doi.org/10.2800/021466

Gómez-Baggethun, E., Gren, A., Barton, D., Langemeyer, J., McPhearson, T., O'Farrell, P., Andersson, E., Hamstead, Z., \& Kremer, P. (2013). Urban ecosystem services. In Urbanization, Biodiversity and Ecosystem Services: Challenges and Opportunities (pp. 175-251). https://doi.org/10.1007/978-94-007-7088-1_11 
Gómez-Baggethun, E., Groot, R., Lomas, P., \& Montes, C. (2010). The history of ecosystem services in economic theory and practice: From Early notions to markets and payment schemes. Ecological Economics, 69, 1209-1218. https://doi.org/10.1016/j.ecolecon.2009.11.007

Gong, C., \& Hu, C. (2016). The way of constructing green block's eco-grid by ecological infrastructure planning. Procedia Engineering, 145, 1580-1587. https://doi.org/10.1016/j.proeng.2016.04.199

Haaland, C., \& Bosch, C. V. D. (2015). Challenges and strategies for urban green-space planning in cities undergoing densification: A review. https://doi.org/10.1016/J.UFUG.2015.07.009

Hartig, T., \& Kahn, P. H. (2016). Living in cities, naturally. Science, 352(6288), 938-940. https://doi.org/10.1126/science.aaf3759

Hartig, T., Mitchell, R., de Vries, S., \& Frumkin, H. (2014). Nature and health. Annual Review of Public Health, 35(1), 207-228. https://doi.org/10.1146/annurev-publhealth-032013-182443

Hofmann, M., Westermann, J., Kowarik, I., \& van der Meer, E. (2012). Perceptions of parks and urban derelict land by landscape planners and residents. Urban Forestry \& Urban Greening, 11. https://doi.org/10.1016/j.ufug.2012.04.001

Holota, T., Kotus, M., Holienčinová, M., Mareček, J., \& Zach, M. (2015). Application of radar chart in the selection of material for clutch plates. Acta Universitatis Agriculturae et Silviculturae Mendelianae Brunensis, 63, 39-43. https://doi.org/10.11118/actaun201563010039

Ives, C., Lentini, P., Threlfall, C., Ikin, K., Shanahan, D., Garrard, G., Bekessy, S., Fuller, R., Mumaw, L., Rayner, L., Rowe, R., Valentine, L., \& Kendal, D. (2016). Cities are hotspots for threatened species. Global Ecology and Biogeography, 25, n/a-n/a. https://doi.org/10.1111/geb.12404

Kambites, C., \& Owen, S. (2007). Renewed prospects for green infrastructure planning in the UK. Planning Practice \& Research, 21(4), 483-496. https://doi.org/10.1080/02697450601173413

Larondelle, N., Haase, D., \& Kabisch, N. (2014). Mapping the diversity of regulating ecosystem services in European cities. Global Environmental Change, 26, 119-129. https://doi.org/10.1016/j.gloenvcha.2014.04.008

Lee, A. C. K., \& Maheswaran, R. (2011). The health benefits of urban green spaces: A review of the evidence. Journal of Public Health (Oxford, England), 33(2), 212-222. https://doi.org/10.1093/pubmed/fdq068

Lin, B. B., \& Fuller, R. A. (2013). FORUM: Sharing or sparing? How should we grow the world's cities? Journal of Applied Ecology, 50(5), 1161-1168. https://doi.org/10.1111/1365-2664.12118

Lindholst, A. (2009). Contracting-out in urban green-space management: Instruments, approaches and arrangements. Urban Forestry \& Urban Greening, 8, 257-268. https://doi.org/10.1016/j.ufug.2009.07.002

Livesley, S., McPherson, G., \& Calfapietra, C. (2016). The Urban forest and ecosystem services: Impacts on urban water, heat, and pollution cycles at the tree, street, and city scale. Journal of Environment Quality, 45, 119. https://doi.org/10.2134/jeq2015.11.0567

Lundy, L., \& Wade, R. (2011). Integrating sciences to sustain urban ecosystem services. Progress in Physical Geography: Earth and Environment, 35(5), 653-669. https://doi.org/10.1177/0309133311422464

Mackerron, G., \& Mourato, S. (2013). Happiness is greater in natural environments. Global Environmental Change, 23, 992-1000. https://doi.org/10.1016/j.gloenvcha.2013.03.010

Marando, F., Salvatori, E., Sebastiani, A., Fusaro, L., \& Manes, F. (2018). Regulating ecosystem services and green infrastructure: Assessment of urban heat island effect mitigation in the municipality of Rome, Italy. Ecological Modelling, 392, 92-102. https://doi.org/10.1016/j.ecolmodel.2018.11.011

Marselle, M. R., Irvine, K. N., Lorenzo-Arribas, A., \& Warber, S. L. (2015). Moving beyond Green: Exploring the relationship of environment type and indicators of perceived environmental quality on emotional well-being following group walks. International Journal of Environmental Research and Public Health, 12(1), 106-130. https://doi.org/10.3390/ijerph120100106

McDonald, L., Allen, W., Benedict, M., \& O'connor, K. (2005). Green infrastructure plan evaluation frameworks. Journal of Conservation Planning, 1(1), 12-43.

McHale, M. R., Pickett, S. T. A., Barbosa, O., Bunn, D. N., Cadenasso, M. L., Childers, D. L., Gartin, M., Hess, G. R., Iwaniec, D. M., McPhearson, T., Peterson, M. N., Poole, A. K., Louie Rivers, I. I. I., Shutters, S. T., \& Zhou, W. (2015). The new global urban realm: Complex, connected, 
diffuse, and diverse social-ecological systems. Sustainability (Switzerland), 7(5), 5211-5240. https://doi.org/10.3390/su7055211

McPhearson, T., Haase, D., Kabisch, N., \& Gren, A. (2016). Advancing understanding of the complex nature of urban systems. Ecological Indicators, 70, 566-573. https://doi.org/10.1016/j.ecolind.2016.03.054

Monteiro, M. V., Handley, P., Morison, J. I. L., \& Doick, K. J. (2019). The role of urban trees and greenspaces in reducing urban air temperatures. Forest Research, 12. https://www.forestresearch.gov.uk/documents/7125/FCRN037.pdf

Moore, T. L. C., \& Hunt, W. F. (2013). Predicting the carbon footprint of urban stormwater infrastructure. Ecological engineering, 58, 44-51. https://doi.org/10.1016/j.ecoleng.2013.06.021

Morris, N. (2003). Health, well-being and open space literature review.

Naumann, S., Davis, M., Kaphengst, T., Pieterse, M., \& Rayment, M. (2011). Design, implementation and cost elements of green infrastructure projects [Report]. https://www.ecologic.eu/11382

Pakzad, P., \& Osmond, P. (2016). Developing a sustainability indicator set for measuring green infrastructure performance. Procedia - Social and Behavioral Sciences, 216, 68-79. https://doi.org/10.1016/j.sbspro.2015.12.009

Pataki, D., Carreiro, M., Cherrier, J., Grulke, N., Jennings, V., Pincetl, S., Pouyat, R., Whitlow, T., \& Zipperer, W. (2010). Coupling biogeochemical cycles in urban environments: Ecosystem services, green solutions, and misconceptions. Frontiers in Ecology and the Environment, 9, 27 36. https://doi.org/10.2307/41149674

Pearlmutter, D., Calfapietra, C., Samson, R., O'Brien, L., Ostoić, S. K., Sanesi, G., \& Amo, R. A. del (Eds.). (2017). The urban forest: Cultivating green infrastructure for people and the environment. Springer International Publishing. https://doi.org/10.1007/978-3-319-50280-9

Pickett, S. T. A., Cadenasso, M., Childers, D., McDonnell, M., \& Zhou, W. (2016). Evolution and future of urban ecological science: Ecology in, of, and for the city. Ecosystem Health and Sustainability, 2, e01229. https://doi.org/10.1002/ehs2.1229

Pretty, J., Peacock, J., Sellens, M., \& Griffin, M. (2005). The mental and physical health outcomes of green exercise. International Journal of Environmental Health Research, 15(5), 319-337. https://doi.org/10.1080/09603120500155963

Romanelli, C., Cooper, D., Campbell-Lendrum, D., Maiero, M., Karesh, W. B., Hunter, D., \& Golden, C. D. (2015). Connecting global priorities: Biodiversity and human health: a state of knowledge review. World Health Organistion / Secretariat of the UN Convention on Biological Diversity. https://cgspace.cgiar.org/handle/10568/67397

Sandifer, P. A., Sutton-Grier, A. E., \& Ward, B. P. (2015). Exploring connections among nature, biodiversity, ecosystem services, and human health and well-being: Opportunities to enhance health and biodiversity conservation. Ecosystem Services, 12, 1-15. https://doi.org/10.1016/j.ecoser.2014.12.007

Seto, K. C., Güneralp, B., \& Hutyra, L. R. (2012). Global forecasts of urban expansion to 2030 and direct impacts on biodiversity and carbon pools. Proceedings of the National Academy of Sciences, 109(40), 16083-16088. https://doi.org/10.1073/pnas.1211658109

Shanahan, D. F., Lin, B. B., Bush, R., Gaston, K. J., Dean, J. H., Barber, E., \& Fuller, R. A. (2015). Toward improved public health outcomes from urban nature. American Journal of Public Health, 105(3), 470-477. https://doi.org/10.2105/AJPH.2014.302324

Termorshuizen, J. W., \& Opdam, P. (2009). Landscape services as a bridge between landscape ecology and sustainable development. Landscape Ecology, 24(8), 1037-1052. https://doi.org/10.1007/s10980-008-9314-8

Tzoulas, K., Korpela, K., Venn, S., Yli-Pelkonen, V. J., Kazmierczak, A., Niemela, J., \& James, P. (2007). Promoting ecosystem and human health in urban areas using Green Infrastructure: A literature review. Landscape and Urban Planning, 81(3), 167-178. https://doi.org/10.1016/j.landurbplan.2007.02.001

United Nation. (2014). United Nations, Department of Economic and Social Affairs, Population Division, 2014. World Urbanization Prospects: The 2014 Revision, Highlights (ST/ESA/SER.A/352). https://esa.un.org/unpd/wup/publications/files/wup2014-highlights.pdfm. 
Valente, D., Pasimeni, M. R., \& Petrosillo, I. (2020). The role of green infrastructures in Italian cities by linking natural and social capital. Ecological Indicators, 108, 105694. https://doi.org/10.1016/j.ecolind.2019.105694

White, M. P., Alcock, I., Wheeler, B. W., \& Depledge, M. H. (2013). Would you be happier living in a greener urban area? A fixed-effects analysis of panel data. Psychological Science, 24(6), 920928. https://doi.org/10.1177/0956797612464659

WHO, (1948). Preamble to the constitution of the World Health Organization as adopted by the International Health Conference, New York, 19-22 June, 1946; signed on 22 July 1946 by the representatives of 61 States (Official Records of the World Health Organization, no. 2, p. 100) and entered into force on 7 April 1948.

WHO. (2015a). Measuring the age-friendliness of cities: A guide to using core indicators. WHO; World Health Organization. http://www.who.int/ageing/publications/measuring-cities-agefriendliness/en/

WHO. (2015b). National healthy cities networks in the WHO European Region. Promoting health and well-being throughout Europe. https://www.euro.who.int/en/publications/abstracts/national-healthy-ities-networks-in-the-whoeuropean-region.-promoting-health-and-well-being-throughout-europe-2015

WHO. (2016). Urban green spaces and health-A review of evidence (2016). WHO. https://www.euro.who.int/en/health-topics/environment-and-health/urbanhealth/publications/2016/urban-green-spaces-and-health-a-review-of-evidence-2016

Wright, H. (2011). Understanding green infrastructure: The development of a contested concept in $\begin{array}{llll}\text { England. Local } & \text { Environment, } & 16(10), & 1003-1019 .\end{array}$ https://doi.org/10.1080/13549839.2011.631993

Wu, J. (2014). Urban ecology and sustainability: The state-of-the-science and future directions. Landscape and Urban Planning, 125, 209-221. https://doi.org/10.1016/j.landurbplan.2014.01.018

Young, R. F. (2011). Planting the living city. Journal of the American Planning Association, 77(4), 368-381. https://doi.org/10.1080/01944363.2011.616996 